超電導デジタルエレクトロニクスの最近の進展

一低消費電力型超電導ネットワークデバイスの開発の現状一

\author{
蓮尾 信也*
}

\title{
Recent Progress in Superconducting Digital Electronics -Recent Status on the Development of Low-power Superconducting Network Devices-
}

\author{
Shinya HASUO*
}

Synopsis: In recent years, the development of superconducting digital electronics has been making rapid progress. A variety of digital circuits based on Single-Flux Quantum (SFQ) device technology such as high-speed switching circuits for router systems and high-speed sampling oscilloscope systems have been demonstrated. These achievements have been mainly based on the NEDO project, "Development of Low-power Superconducting Network Devices". This paper describes these recent progress and future prospects of superconducting digital electronics.

Keywords: SFQ device, network device, switching circuit, sampler circuit

\section{1. はじめに}

インターネットや携帯電話の普及に伴い、これまでとは 比べ物にならないほど多くの情報が瞬時にして得られるよ うになり、生活の質（Quality of Life）は大きく向上し た。しかし、この状況を維持発展させるためには、裏方と なるインフラ技術のたゆまざる進歩が要求される。具体的 にいえば、 5 年で 10 倍にも増える情報量を処理するため の IT（情報技術）システムの高速化をどのように実現し ていくのか、また何 MW も消費するルータやサーバの膨 大な電力使用量をどのようにして抑制するのか、など大き な課題を解決しなければならない。しかし、従来技術の延 長では、急速に増大するネットワークの要求に応えること が困難となり、ルータや基地局通信機器の処理能力不足に 起因するネットワークの停滞や、サーバの消費電力増大に 起因する設置の制約などが懸念されている ${ }^{1)}$

このような状況の下、新エネルギー・産業技術総合開発 機構（NEDO）によって 2001 年に新しいプロジェクトの 基本計画が策定された ${ }^{2)}$ 。これまでの半導体デバイスとは

\footnotetext{
Received March 24, 2008

* (財)国際超電導産業技術研究センター 超電導工学研究所

干135-0062 東京都江東区東雲一丁目 10-13

International Superconductivity Engineering Center,

Superconductivity Research Laboratory,

10-13, Shinonome 1-chome, Koto-ku, Tokyo 135-0062, Japan

E-mail: hasuo@istec.or.jp
}

全く異なる原理で動作する高速・低消費電力の超電導デバ イスを開発し、デバイス性能に起因するネットワーク機器 の高速化の限界、消費電力の増大等の問題を根本的に解決 しようとするものである。具体的には、（1）情報通信基盤 の重要な構成要素であるルータ用スイッチ、サーバ用プロ セッサに応用可能なニオブ系超電導デバイス技術を開発 し、これらを実装したモジュールの性能実証を行うこと、 および（2）基地局通信機器および超高速計測機器への応 用が期待される酸化物系高温超電導デバイスの技術を開発 し、小型冷凍機に実装した小規模システムの性能実証を行 うことである。もっと簡潔に言えば、超電導デバイスを用 いることによって、先に述べたようなネットワーク社会の 抱える笨状を救える可能性があるのかどうか、を示すこと がこのプロジェクトに課された使命であった。

このような目的で、「低消費電力型超電導ネットワーク デバイスの開発」プロジェクトは、2002 年 9 月に開始さ れた。(財)国際超電導産業技術研究センター（ISTEC）が経 済産業省からの委託を受けた。この時点では低温超電導材 料であるニオブを用いた超電導デバイス技術の研究開発だ けがスタートした。2003 年度からは、経済産業省からの 直接委託ではなく、NEDO からの委託事業として引き継 がれた。そしてニオブ系低温超電導デバイスだけでなく、 酸化物系高温超電導デバイスを使った超高速システムもプ ロジェクトに含まれることになった。2007 年 3 月にプロ ジェクトが終了した。ニオブ系デバイスは約 4 年半、酸化 
物系デバイスは 4 年間の研究開発を行った。

このプロジェクトにおいて、ニオブ系デバイス、酸化物 系デバイスともに大きな進歩を遂げ、プロトタイプシステ ムの動作実証を行うことができるまでになった。超電導デ ジタルエレクトロニクスは本文で述べるように、30 年以 上前から研究開発が行われている。しかしながら、このプ ロジェクト期間内における進歩はそれまでの進歩の速度を 大きく上回るものであったといえる。

本稿では、このプロジェクトに係ってきた筆者が超電導 デジタルエレクトロニクスの進展を述べるとともに、この プロジェクトで得られた成果の意義を振り返ることにした い。

\section{2. 超電導デジタルエレクトロニクスの流れ}

ここで超電導現象を用いたデジタル回路の研究開発の流 れを簡単に振り返って見る。

デジタル回路を構成するための基本となる能動素子は ジョセフソン素子である。この素子を用いたデジタル回路 の最も大きな特徴は、消費電力が小さく、動作速度が速い ことである。ジョセフソン素子で半導体に代わる高速回路 を作る試みは 30 年以上前からあった。図 1 に示すよう に、1960 年代後半から IBM がジョセフソン素子を用いた 高速コンピュータの開発を進めていた。それに刺激されて 日本でも 1982 年 1 月から 8 年間、通産省（当時）の大型 プロジェクト「科学技術用高速計算システムの研究開発」 の中でジョセフソン素子をコンピュータに適用するための 研究開発が進められた。その当時の超電導材料は鉛を主材 料にした鉛合金であり、非常に特性が不安定であった。そ の後、低温超電導材料（LTS）であるニオブを用いたジョ セフソン素子が主に用いられるようになった。さらに 1986 年に高温超電導材料（HTS）が発見されると、それ

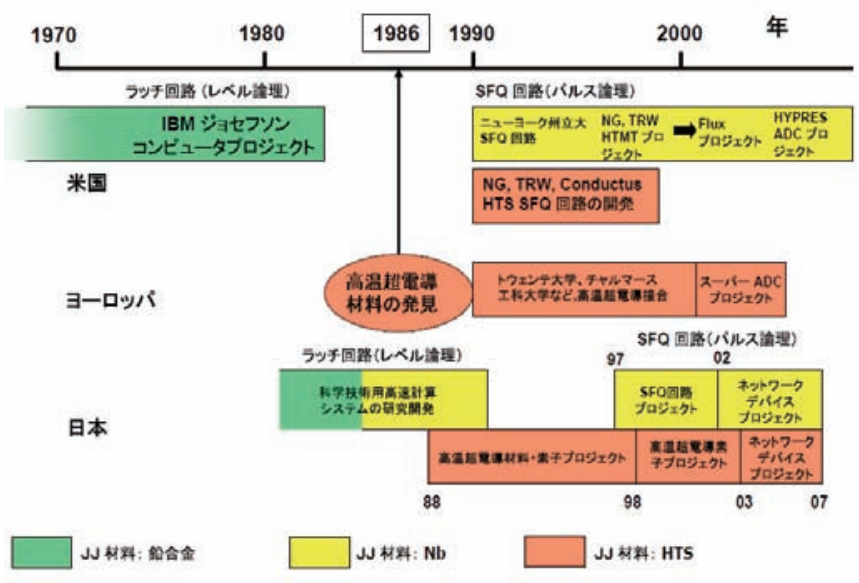

図 1 日米欧における超電導デジタルエレクトロニクス の流れ
を用いたジョセフソン素子の開発が進められた。

日本では、一時期 HTS 超電導材料を用いたジョセフソ ン素子の開発に集中したが、HTS 材料の困難さが見えて くるとニオブを用いたジョセフソン素子の開発が復活し た。しかも、従来の動作方式とは異なる回路を適用するこ とになった。それまではラッチ回路と呼ばれる方式であっ た。ジョセフソン素子の両端に約 $3 \mathrm{mV}$ の電圧が発生して いるかどうかを 2 進数の“1”と“0”に対応させるもので ある。しかしこの方式ではクロック周波数がせいぜい $10 \mathrm{GHz}$ 程度までしか動作できない。半導体回路の進歩が 目覚しく、ラッチ回路では半導体にいずれ追いつかれるこ とが明白になってきた。90 年代に入ると、ラッチ回路に 代わって SFQ（Single Flux Quantum）回路が用いられるよ うになった。SFQ 回路については次章で述べるが、ラッ 于回路に比べてさらに消費電力が小さく、100 GHz 以上の クロック動作が可能である。

1997 年から 2001 年まで通産省(当時)や科技庁(当時)の プロジェクトの中で LTS および HTS を用いた SFQ 回路の 研究開発が進められた。そして 2002 年から「低消費超電 導ネットワークデバイスの開発」に技術が受け継がれて 行った。

一方、米国ではどちらかといえば LTS デバイス開発に 力を入れ、HTMT プロジェクト ${ }^{3}$ やそれに続く Flux プロ ジェクト ${ }^{4)}$ が進められた。現在はこれらのプロジェクトは 終了し、HYPRES 社を中心としたデジタル通信システム の開発が進められている。衛星経由の電波を受信し、LTS 超電導デバイスでその後の信号処理を行うシステムであ る。海軍や空軍の研究所に納入され、フィールドテストが 行われている5)。

欧州ではどちらかといえば HTS に力を入れ AD 変換回 路などの研究が行われた。現在は具体的なシステムを目指 すことより基礎的な研究に力を入れている ${ }^{6)}$ 。

\section{SFQ 論理回路とは}

SFQ 回路というのは、ジョセフソン素子を含む超電導 ループの中に、磁束量子 1 個が含まれている場合を 2 進数 の “1”に対応させ、含まれていない場合を“0”に対応さ せて論理演算を行うものである ${ }^{7)}$ 。SFQ を論理回路に用い る動機は大きく 2 つある。1 つは超高速の応答速度であ り、もう 1 つは極低消費電力である。状態 “ 1 ”から“0” へ、あるいは“0”から“1”へ切り替える時間（スイッチ ング時間）が数 ps と非常に短い。また、AND や OR など の論理ゲート当たりの消費電力が $1 \mu \mathrm{W}$ 以下である。超高 速あるいは極低消費電力のいずれかを実現できる素子は数 多く存在する。しかしその両方を同時に実現できるものは SFQ 回路をおいてほかにない。このため、クロック周波 数が 20〜100 GHz 程度の超高速 LSI が実現できると期待 
されている。

図 2 にSFQ 論理回路の基本構成を示す。基本的な構成 要素はジョセフソン素子 2 個を含む超電導ループである。 超電導ループの中に磁束量子が出入りする瞬間だけジョセ フソン素子の両端に電圧が現れる。これが $\mathrm{SFQ}$ パルスで ある。 $\mathrm{SFQ}$ パルスの幅は数 $\mathrm{ps}$ で電圧振幅は $1 \mathrm{mV}$ 程度で ある。このような超電導ループを図 2 のように並べて、例 えば入力信号 A と B が 2 つともつてきたら出力信号 $\mathrm{C}$ が得られるようにすれば AND ゲートとして動作する。

A、B どちらか一方が入ったら C に出力パルスが得られる ように設計すれば OR ゲートとなる。ある瞬間に時間を止 めてみれば、超電導ループの中に磁束量子が 1 個入ってい る場合と何もない状態が存在する。これが SFQ（単一磁 束量子）回路と呼ばれる所以である。

SFQ 論理回路の中では、このように数 ps という非常に 短いパルスを用いて論理動作を行わせるので、20〜100 $\mathrm{GHz}$ 程度の高速クロック周波数で動作させることが可能 である。論理回路におけるクロックというのは、音楽にお けるメトロノームのような役割と考えればよい。すなわ ち、回路動作のリズムを決めるものである。100 GHz のク ロック周波数で動いている回路では、クロックが一周期す る時間は $10 \mathrm{ps}$ であり、その間にまとまった論理演算を行 うことになる。

SFQ 論理回路も半導体回路と同様に AND や OR ゲート などの基本要素回路を組み合わせて複雑な LSI 回路を構成 することが可能である。

\section{4. 「低消費電力型超電導ネットワークデバイスの 開発」プロジェクト}

先に述べたように、本プロジェクトは 2002 年 9 月に LTS デバイスの研究開発が開始され、2003 年 4 月からは HTS デバイスの開発も並行して進められた。

プロジェクト開始以前には、高温系デバイスが実現でき るのなら低温系は不要ではないかという議論があった。し かし、低温系と高温系は次のような利害得失を有し、どち

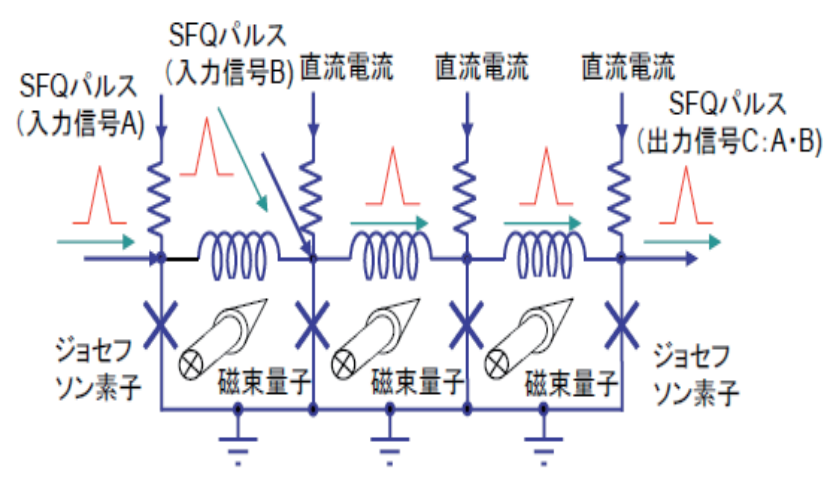

図 $2 \mathrm{SFQ}$ 論理回路の基本構成
らか一方で事足りるものではない。低温系は、材料および 動作が安定で、高集積化が比較的容易という長所がある反 面、冷却機構の小型化および室温空間との接続に高度な技 術課題がある。一方高温系は、冷却機構の課題が比較的軽 微であるが、微細加工や集積化プロセスの難度が高いた め、高集積化が課題となっている。半導体においても $\mathrm{GaAs}$ などの化合物半導体と $\mathrm{Si}$ 半導体ではそれぞれ応用分 野が異なっていることを考えれば、低温系と高温系の役割 分担が理解できる。低温系は冷却が比較的大掛かりになる ことからルータやサーバなどの大規模システムに向いてお り、高温系は高速計測器や小規模通信機器などの小型・高 速機器に向いている。

このように相反する得失を有する低温系と高温系の技術 開発を同一プロジェクト内で行った。このことは一方の得 意技術を他方の不得意部分に応用することが容易となり、 それぞれの課題解決が加速されるという相乗効果が期待で きたからである。

本プロジェクトは、超電導技術の実用化フェーズまでの 実証を目標範囲とし、最終製品を想定したうえで目標設定 を行った。二オブ系低温超電導回路では、基幹系ネット ワークにおけるハイエンドルータを想定し、集積度を 10 万ジョセフソン接合規模まで高めることを最終目標とし た。それにより、例えば 1 モジュールで 1 Tbps (bps=bit per second）のデータをやり取りするスイッチモジュール の動作を実証することとした。また、ハイエンドサーバを 想定して、超高速プロセッサモジュールのプロトタイプの 動作実証も行うこととした。一方、酸化物系高温超電導回 路では、無線基地局通信機や計測器などの小規模機器への 適用を想定し、集積度を 500 接合規模まで高めることを最 終目標とした。それにより、アナログ - デジタル (AD) 変換回路における要素回路の $50 \mathrm{GHz}$ 動作、および計測回 路における $100 \mathrm{GHz}$ の電気・光信号の計測動作を実証す ることとした。

本プロジェクトの研究開発体制を図 3 に示す。本プロ ジェクトを成功させるために、分散した組織にテーマを分 担させるということではなく、できる限り集中して共同作 業ができるようにした。このため必要と判断したテーマに は企業や大学から ISTEC の超電導工学研究所 (SRL) に出 向させるなどによって、最適体制を作り上げた。しかも、 超電導デバイス研究者だけでなく、半導体の専門家にも参 加してもらって、幅広い技術を導入できるようにした。プ ロジェクトリーダは名古屋大学の早川尚夫教授 (当時、現 名誉教授)が務められた。この体制の下で、図 4 に示すよ うなスケジュールでプロジェクトは進められた。

ニオブ系低温超電導デバイスと酸化物系高温超電導デバ イスとでは目標システムやその規模は異なっているが、超 電導デバイスの早期実用化を実現するために最適なシステ ムをターゲットに選んでおり、実用化時期もほぼ同じであ 
る。このため、共通に開発すべき要素も多いので、低温と 高温のデバイス技術が相互に関連し連携をとりながら進捗 した。

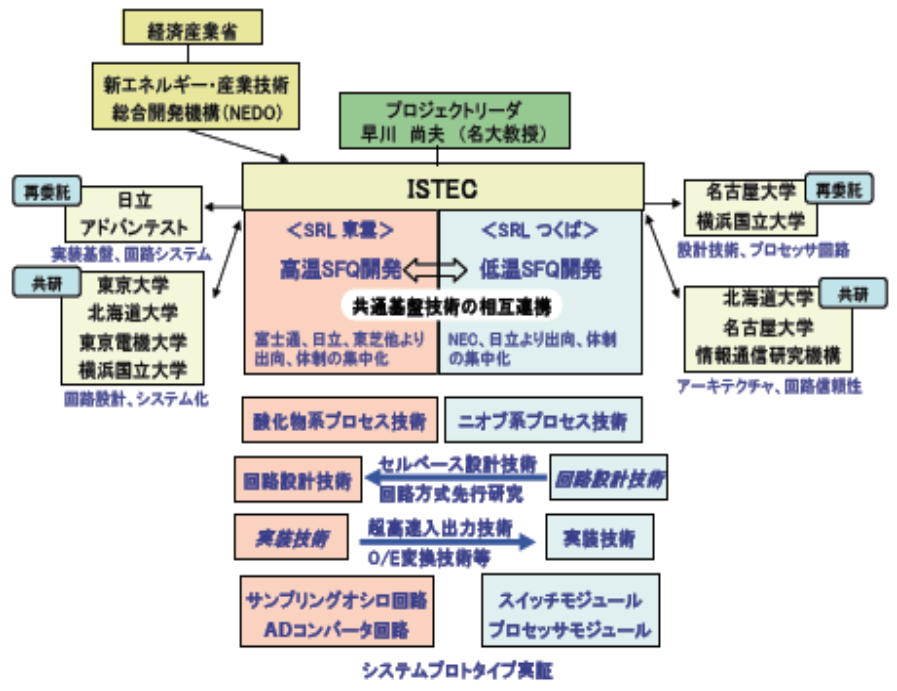

図 3 プロジェクトの推進体制
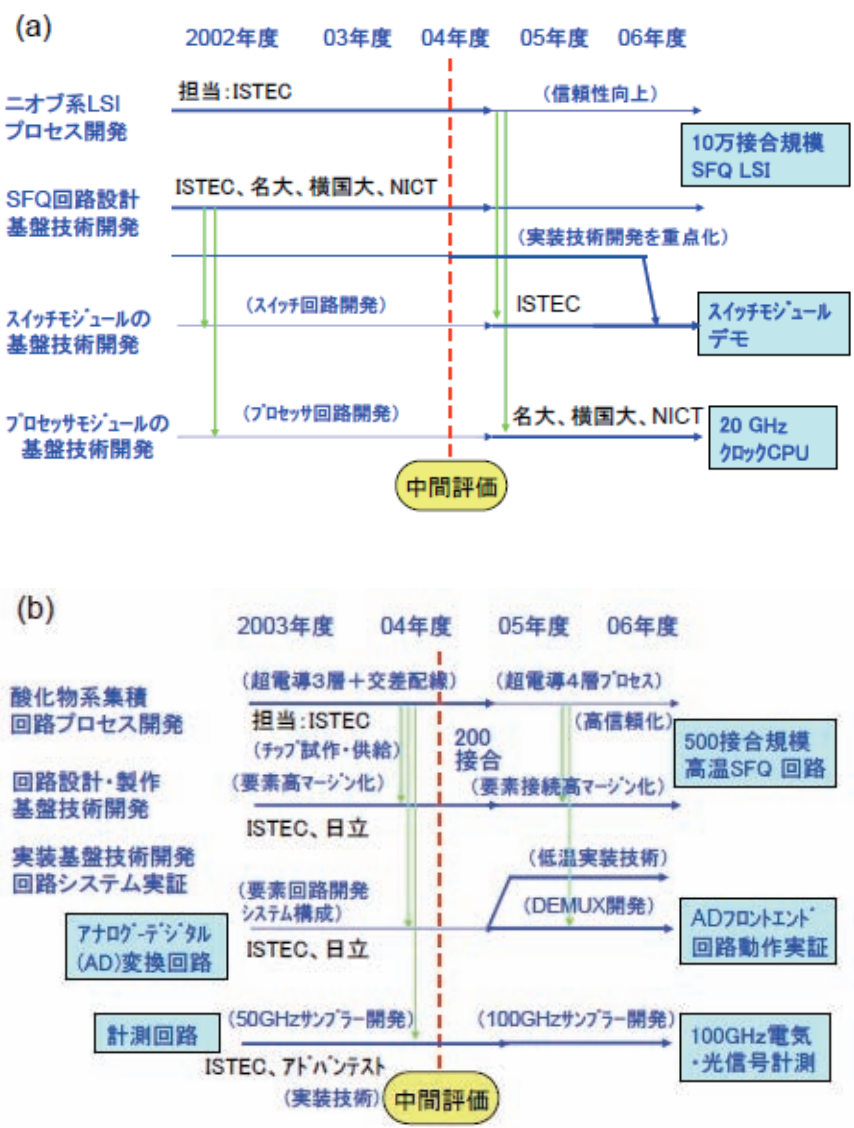

図 4 プロジェクトの研究開発スケジュール、(a) は ニオブ系低温デバイス、（b) は酸化物系高温デバイス

\section{5. プロジェクトの成果 ${ }^{8)}$}

プロジェクト期間内に得られた LTS および HTS デバイ スの主な成果を以下に述べる。

\section{1 ニオブ系低温超電導デバイス開発}

2002 年 9 月に開始されたニオブ系低温超電導デバイス では、このプロジェクトに期間中に多くの重要技術を開発 することができた。図 4(a)のスケジュールに示した各研 究項目に沿って開発した技術を述べる。

\section{1 .1 ニオブ系LSI プロセス開発}

これまでニオブ系集積回路を作製する場合は、回路の配 線層を重ねるにつれて凹凸が激しくなり、ニオブ配線層を 4 層以上重䄈ることは困難であった。そこで CMP（化学 機械的研磨）技術を導入し、ニオブの配線層の間の $\mathrm{SiO}_{2}$ 絶縁膜の表面を平坦化した（図 5 参照）。この平坦化法や 高臨界電流密度の微小ジョセフソン接合形成法などの要素 技術開発に成功し、これらを統合したアドバンストプロセ ス（ADP）と名付けた新プロセスを開発した。ADP の主 な仕様は、最小線幅 $0.8 \mu \mathrm{m}(1.5 \mu \mathrm{m})$ 、最小接合面積 1.0 $\mu \mathrm{m}^{2} \quad\left(4.0 \mu \mathrm{m}^{2}\right)$ 、臨界電流密度 $10,000 \mathrm{~A} / \mathrm{cm}^{2} \quad(2,500$ $\left.\mathrm{A} / \mathrm{cm}^{2}\right) 、$ ニブ 9 層（3 層）、シート抵抗 $2.4 \Omega / \Upsilon(1.2$ $\Omega / \Upsilon)$ 、積層コンタクト (単層のみ) であり、す心゙ての項 目において目標を満足することができた ${ }^{9)}$ 。なお括弧内 は、本プロジェクト開始以前の標準プロセスでの值であ る。とくに、平坦化法により可能となったニオブ層数の増 加は、本プロジェクトの重要な成果の 1 つであるといえ る。ADPを用いて、 8 ビットシフトレジスタ、100 万個 SQUID アレイ、および $16 \mathrm{kRAM} の 3$ 種類の回路が試作さ れた ${ }^{9)}$ 。 8 ビットシフトレジスタでは、120 GHzまでの正 常動作が確認され、SFQ 回路も半導体回路と同様に微細 化により動作速度が向上するスケーリング則が成り立つこ とが証明された ${ }^{10)}$ 。100 万個 SQUID アレイでは、配線や 層間のショートや断線が全くないチップが得られ、ADP の信頼性の高さが示された。約 8 万接合からなる $16 \mathrm{kRAM}$ では、従来の標準プロセスに比べて 5.7 倍の集積 度向上が示されるとともに 10 万接合規模回路の動作が可 能なことが示された。

\subsubsection{SFQ 回路設計基盤技術開発}

SFQ 回路に適した論理合成ツール、自動配置配線ツー ルを開発し、論理記述言語から SFQ 回路のレイアウトが

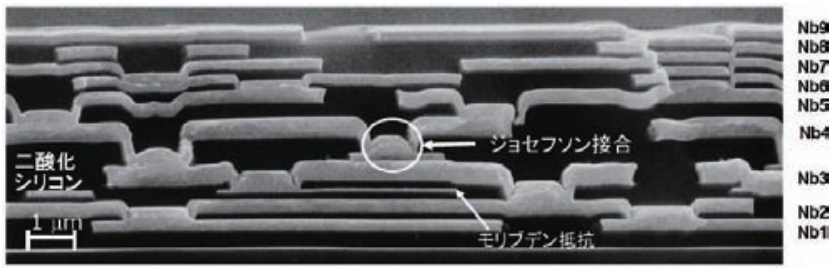

図 5 平坦化したニオブ系 LSI の断面構造 
自動的に生成できる環境を構築した。この論理合成ツール によって、通常の半導体 LSI 設計に使われている HDL (ハードウェア記述言語)で論理動作を記述すれば、SFQ に 適した論理回路が合成されるようにした。例えば、HDL で乗算を行う記述をすれば、SFQ の AND ゲートや OR ゲートなどを組み合わせた乗算器回路のブロック図が得ら れる。さらに自動配置配線ツールを用いると、この論理回 路からマスクパーンレイアウトを発生させることができ る。このことは、SFQ 回路技術者しか設計できなかった 回路を、一般的な半導体技術者でも設計できるようになっ たことを意味しており、画期的な成果であるといえる。実 際に、40 万接合からなる RISC プロセッサを設計すること ができた。40 万接合のプロセッサが $27.6 \mathrm{GHz}$ で動作でき ることをシミュレーションにより確認した ${ }^{11)}$ 。

\subsection{3 スイッチモジュールの基盤技術開発}

SFQ スイッチと CMOS ラインカードを用いたルータ アーキテクチャを提案し、100 Tbps クラスの大容量ルータ 用低消費電力スイッチが構築可能であることを示した。パ ケットスイッチLSI として、データ経路の切り替えを行う $4 \times 4$ スイッチ、2 つ以上の信号が同時に同じ経路を辿るの を防ぐための $4 \times 4$ スケジューラ、スケジューラつき $4 \times 4$ スイッチを開発し、いずれも $40 \mathrm{GHz}$ 動作を確認し た ${ }^{12,13)}$ 。また、基本単位となる $2 \times 2$ スイッチを小型化 し、それらを用いた $16 \times 16$ スイッチの動作を確認した。 これらのチップ写真を図 6 に示す。

図 4(a)に示したように、中間評価以降はとくに実装技術 の開発に力を注いだ。中間評価の結果、評価委員の方々か らプロトタイプシステム実現のために実装技術を強化すべ きとのご意見を頂いたためである。そこで MCM（Multi Chip Module）技術、極低温広帯域プローブ技術、冷凍機 実装技術、SFQ 出力電圧昇圧技術などを開発した。これ らのシステム化技術でスケジューラ付き $4 \times 4$ スイッチを 冷凍機に実装したスイッチプロトタイプシステムを作製
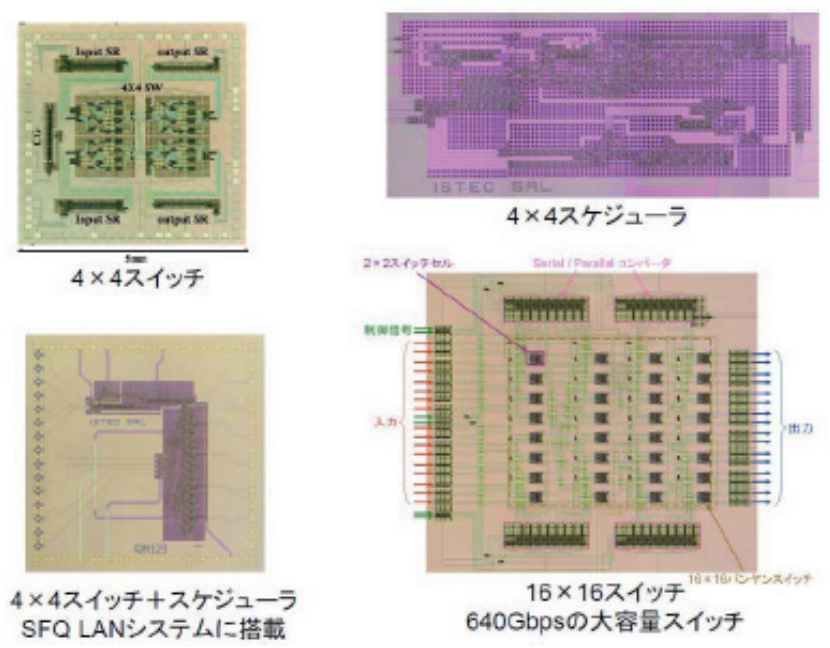

図 6 スイッチ用各種回路のチップ写真
し、この装置を用いて 4 台のパソコンを結合した LAN に よるパソコン間画像転送実験に成功した（図 7） 14)。この 実験においてすべてのチャンネルで通信応用に十分な $10^{-13}$ 台の低いビット誤り率（BER）が得られた ${ }^{15)}$ 。さら に室温での光電変換により光ファイバーと接続した SFQ 2 ×2 スイッチの $40 \mathrm{Gbps}$ 連続データに対する安定動作を確 認した。これらは SFQ を用いた超電導デジタル回路の能 力を室温に引き出した世界初の実験である。また、これら のシステムに使用しているスイッチチップは、それぞれ 160 Gbps、80 Gbps の高いスループットであるにもかかわ らず、1 $\mathrm{mW}$ 以下の消費電力で実現できている。これは SFQ の低消費電力性を十分に印象付けることができる成 果だと考えられる。

これらのデモに用いた MCM 技術にも大きな進展が見ら れた。MCM というのは、図 8 に示すように、シリコン基 板でできたボード上に複数の SFQ チップを半田バンプで 接続したものである。 MCM ボード上にはニオブを用いて 必要な配線が形成されている。この MCM 上に実装した複 数の SFQ 回路チップの間で、100 Gbps 以上の高速信号の

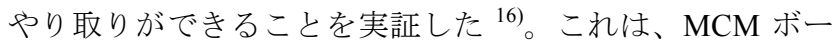
ドがあたかも 1 つの大きなチップであるかのように動作さ せることができることを意味しており、半導体では実現で きなかったウェハースケールコンピュータの可能性を示し たものといえよう。

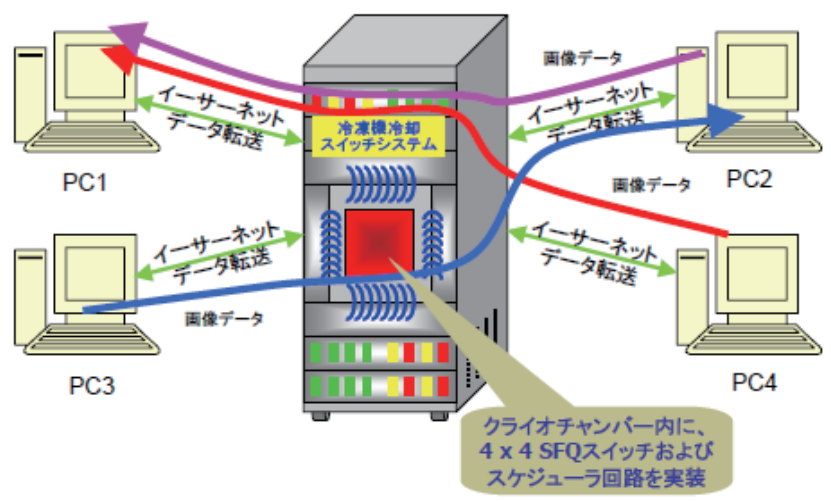

図 7 SFQ4×4 スイッチを用いた画像伝送実験概念図

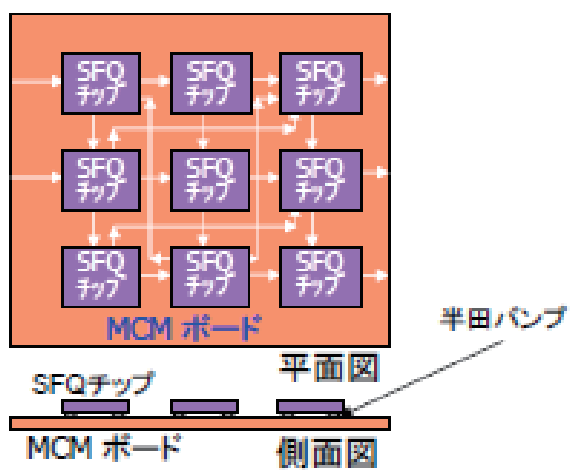

図 8 SFQチップを MCM ボードに実装した概念図 


\subsection{4 プロセッサモジュールの基盤技術開発}

この技術は主に名古屋大学と横浜国大のチームによって 開発が行われた ${ }^{17)}$ 。SFQ に適した 4 ビットシリアル ALU など数多くの要素回路の開発を行った。この中で、 CORE1 $\gamma$ プロセッサ用キャッシュメモリの $36 \mathrm{GHz}$ 動作な ど多くの要素回路が、25 GHz 以上の高速で動作してい る。これらの要素回路を用いて同期式プロセッサ CORE1 $\alpha$ シリーズや非同期プロセッサ SCRAM2 の開発を行っ た。CORE1 $\alpha$ では最高 7,220 接合を用いたプロセッサの $21 \mathrm{GHz}$ 動作に成功した。SCRAM2 は 8,197 接合で構成 し、すべての正常動作を確認できた。また、2 個の ALU をカスケード接続した 10,995 接合からなるプロセッサ CORE1 $\beta$ を開発し、命令に対して最高 $25 \mathrm{GHz}$ 、データに 対して最高 $17 \mathrm{GHz}$ まで正常動作を確認できた。このとき の消費電力は $3.4 \mathrm{~mW}$ であり、SFQ 回路の低消費電力性を 示すことができた。

\section{2 酸化物系高温超電導デバイス開発}

酸化物系高温超電導デバイス開発は、2003 年 4 月より 本プロジェクトの中の開発項目として組み込まれた。その 後の 4 年間でプロトタイプシステム実現まで達成すること ができた ${ }^{18)}$ 。困 4(b)の各研究開発項目の主な成果を以下 に示す。

\subsection{1 酸化物系集積回路プロセス開発}

それまでの酸化物系集積回路は、ジョセフソン素子を含 む単純な構造のものしか作れなかった。このプロジェクト で目指したものは、超電導配線層や抵抗層を含む超電導 4 層の積層構造の作製技術と最小線幅 $1 \mu \mathrm{m}$ の回路加工技術 である。これらの技術開発の結果、酸化物系集積回路と呼 ベる構造を実現することができた。このためには、プロセ ス途中の熱によってジョセフソン素子特性を劣化させない 工夫などが必要であった。また、超電導配線層を形成した 後の表面を $2 \mathrm{~nm}$ 程度の極限まで平坦に形成する技術の確 立によって、作製ごとのジョセフソン素子特性のばらつき (臨界電流の変動) を $14 \%$ に抑えることができた。これら の技術は SFQ 回路だけでなく、積層構造を有する高性能 SQUID 実現など高温超電導デバイス全体に有効な大きな 波及効果をもつ成果である。

ジョセフソン素子の臨界電流密度 $\left(J_{\mathrm{c}}\right)$ の集積回路内で の均一化についても大きな飛躍があった。これまでのジョ セフソン素子は接合の下部電極の大きさはまちまちであっ た。接合の臨界電流は上部電極の幅で決まり下部電極の寸 法には依存しないと考えられていたからである。しかし、 実際に作製した集積回路内のジョセフソン素子の $J_{\mathrm{c}}$ をす べて測定すると、図 9(a)に示すように、下部電極の大きさ によって $J_{\mathrm{c}}$ が 2 倍近く変化することが分かった。これ は、プロセス途中の熱的な効果に起因すると考えられる。 そこで回路内における下部電極を分離しそのサイズをそろ
えることにより図 9(b)のように $J_{\mathrm{c}}$ 分布を抑制することが できるようになった。この方法は、SBL (Separated Baseelectrode Layout） と呼ぶ新たな酸化物系回路レイアウト法 の開発に結びついた ${ }^{19)}$ 。

$40 \mathrm{~K}$ 程度の高温で特性の良好なジョセフソン素子を再 現性よく実現する新たな接合作製技術を開発し、後で述べ るサンプラーの広帯域動作実証に大きく貢献した。さら に、サンプラー回路などの複雑な作製プロセス途中におい て逐次特性評価する低温および室温プローバを開発した。 これにより、接合特性の劣化をもたらす酸化物超電導層や 接合からの酸素抜けをモニタすることができ、回路歩留ま りを大きく向上することができた。

\subsection{2 回路設計・製作基盤技術開発}

ジョセフソン素子の臨界電流 $I_{\mathrm{c}}$ のばらつきや動作温度 による変動など高温超電導回路特有の課題を考慮した回路 設計技術を開発し、種々の SFQ 要素回路に対し $\pm 20 \%$ 以 上の動作マージンが得られるような設計が可能となった。 一方、回路動作の実証に関しては、回路中の接合 $J_{\mathrm{c}}$ の均 一化を可能とする新しい回路レイアウト法である前述の SBL 法の開発が大きなブレークスルーとなった。さら に、寄生インダクタンスや寄生容量を低減する回路レイア ウトを採用することにより、いろいろな集積回路を実現す ることができた。図 10 には試作例としてトグルーフリッ プ・フロップ（T-FF）回路および後に述べるサンプラー チップの写真を示す。T-FF では $210 \mathrm{GHz}$ 動作を達成し、 酸化物系回路としては従来の 3 倍以上の動作周波数の向上 が実現できた。また、AND ゲート、OR ゲート、イン バータゲートなどほぼすべての SFQ 要素回路の論理動作
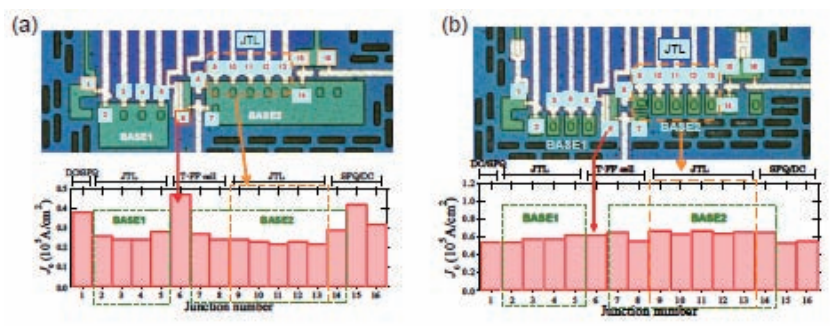

図 9 (a)従来のレイアウト（左上）と臨界電流のばら つき、および(b)SBL (右上) と臨界電流のばらつき

(a)

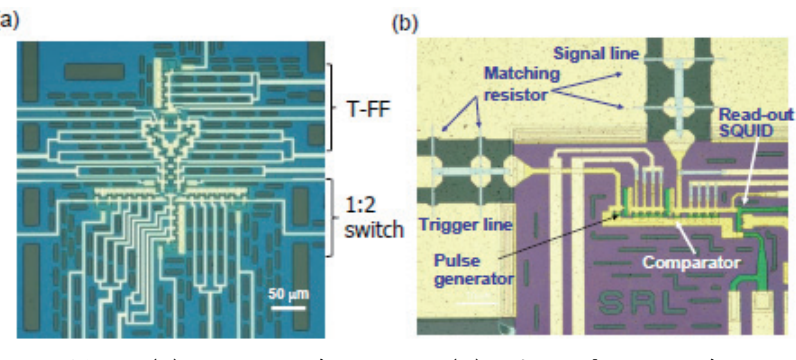

図 10 （a） T-FF 回路および（b）サンプラー回路の チップ写真 
を確認することができた。複数の要素を接続した 50 素子 からなる 1:2 分周回路（DEMUX 回路）などの機能回路 動作を酸化物系で初めて実証することができた。

\subsection{3実装基盤技術開発および回路システム実証}

実装技術開発では、小型冷凍機冷却を可能とする電気信 号用軽量化入力モジュールや、光信号用の広帯域フォトダ イオード一体型非磁性モジュールを開発した。この結果、 サンプラー回路（図 10(b)）へ50〜100 GHz の高周波電気 信号および光信号を導入しての試験を可能とした。

これらの実装技術を用いて、サンプラー波形計測（サン プリングオシロスコープ）デモシステムを構築した。図 11 にデモシステムの全体を示す。1 段式スターリング クーラーを用いた重量 $4 \mathrm{~kg}$ 以下の冷却系と、トリガー ジッタを $1 \mathrm{ps}$ 程度に改良したシステムを開発した。これ を用いて、 $45 \mathrm{~K}$ 動作温度への 1 時間以内の冷却と、50 $\mathrm{GHz}$ 以上の広帯域特性の実証に成功した。最終目標であ る $100 \mathrm{GHz}$ の信号計測が十分可能であることが示される と共に、素子特性の最適化により、半導体製品を超える $100 \mathrm{GHz}$ 帯域が実現可能という見通しを得ることができ た。

そのほかに、アナログ - デジタル変換（AD コンバー タ）システムの性能実証を目指した。酸化物系高温超電導 プロセスで作製可能な比較的集積規模の小さな（500 接合 以下）超電導フロントエンド回路と、半導体信号処理回路 （バックエンド回路）を組み合わせたハイブリッド型シグ

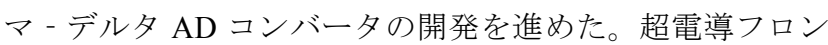
トエンド回路中の変調器、DEMUX、ドライバなど要素回 路の設計最適化をニオブ系試作を利用して行った。これを 新たに開発した半導体バックエンド回路と接続したシステ ムを構築し、10 MHz 帯域で S/N 比 13.7 ビットという世界 最高性能を実証した ${ }^{21)}$ 。ハイブリッド型の構成でも理論 值に近い高性能が得られることを示すことができた。ま

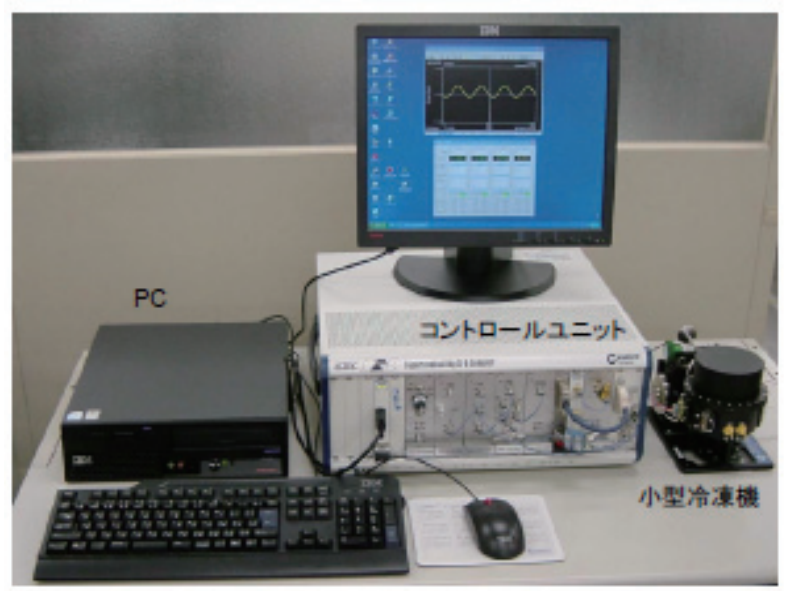

図 11 酸化物系高温超電導 SFQ デバイス（右側の小 型冷凍機内に実装）を用いたサンプリングオシロス コープのプロトタイプ
た、変調器の多並列化やサンプリング周波数の増加により 半導体では実現が困難である $200 \mathrm{MHz}$ 帯域で 12-14 ビッ 卜精度という性能への見通しを得ることができた。これ は、次世代移動体通信基地局通信機に必要とされる性能で ある。

本プロジェクトで開発した酸化物系プロセス技術、回路 設計製作技術は従来の水準から大きく進歩した。実際に小 型冷凍機の中に実装した SFQ 回路（グランドプレーンを 有する積層構造をもつもの）が $100 \mathrm{GHz}$ 以上の高速で動 作することを実証した例は類を見ない。本プロジェクトで は従来の約 8 倍以上の 200 接合を超える規模の回路動作が 実証された。AD コンバータについては、米国の HYPRES 社およびノースロップ・グラマン社で主として軍事無線通 信用のシステム開発が進められている。欧州でも本プロ ジェクトと類似の高温超電導 $\mathrm{AD}$ コンバータの開発が Twente 大などで進められた ${ }^{6)}$ 。本プロジェクトでは、高温 回路に拡張可能なハイブリッド型の構成で、HYPRES 社 の全ニオブ $\mathrm{AD}$ コンバータを超える性能を得ることができ た。また、高温超電導回路については、変調器回路のみな らず DEMUX のような機能回路の動作を初めて実証でき たことは大きな技術的進歩といえる。高温超電導サンプ ラーについては、実用的なコンパクトなデモシステムで半 導体製品を超える性能を実現できる見通しを得ることがで きた。

\section{6. 今後の展望}

本プロジェクトの最終的な成果物は、ルータ用スイッチ モジュール、サーバ用プロセッサモジュール、アナログ デジタル（AD）変換回路、サンプリングオシロ回路シス テムである。これらはいずれも通信、情報、計測分野にお いて性能を代表的に表わすシステムである。したがって、 これらのシステムが半導体では実現不可能な性能を達成で きることを示すことにより、次の段階である SFQ システ ムの実用化へ向けて大きく前進することができた。

本プロジェクトで示した各種デモンストレーションによ り、SFQ 技術が多くの技術的ハードルを越えたことを実 証した。低温でいえば、室温から入力した $40 \mathrm{Gbps}$ の光 信号を電気信号に変換した後、冷凍機内に実装されている スイッチで処理されて、再び室温に戻った電気信号を光信 号に変換しファイバーに通せることを示した。高温では小 型冷凍機の中に実装したサンプラーチップに、電気信号も 光信号も入力できるようにして、それぞれの波形観測でき ることを示した。低温、高温ともに本プロジェクトの成果 は企業の専門家から高い評価を得ている。しかし、それが すぐにビジネス展開に直結する訳ではない。企業がビジネ ス展開を念頭において開発を始めるための判断材料となる 性能を示すことが必要である。今後はこれらの技術をもと 
に具体的応用を志向したシステムの開発を行い、企業の審 判を受けることになろう。それが成功すれば、いわゆる “死の谷”を越えたと判断される。超電導デジタルエレク トロニクスの実用化のためには、“死の谷”越えを目指し たあと一歩の継続した努力が必要である。

今後の実用化を目指すフェーズで問題となるのは、SFQ は新しい技術であるため初期投資が大きいことである。そ れゆえ一定の初期投資が必要な製造ラインは別に用意して おき、そこから各企業がチップを購入するという方法が、 SFQ 市場参入の壁を低くするために有効であると思われ る。このような SFQ チップファンドリサービスを行う機 関として、本プロジェクトの成果を核とした組織を立ち上 げる必要がある。SFQ チップを購入する企業からすれ ば、より少ない投資で SFQ システム製品の開発に着手す ることができるものと考えられる。

30 年以上も前から超電導デジタルエレクトロニクスに 係って来た者の実感として、更なる努力を重ねて一日も早 い実用化を目指したいと考えている。

本稿では、新エネルギー・産業技術総合開発機構の「低 消費電力型超電導ネットワークデバイスの開発」プロジェ クトの中で得られた成果を中心に述べた。早川尚夫プロ ジェクトリーダはじめ、関係各位の多大な努力によって得 られた成果であることを記し、その成果をこのような形で 報告できることに感謝の意を表します。

\section{参 考 文 献}

1) 小笠原敦：「情報通信のエネルギー問題一求められる通信イ ンフラの省電力化一」http://www.nistep.go.jp/achiev/ftx/jpn/ stfc/stt063j/0606_03_featurearticles/0606fa01/200606_fa01.html

2) NEDO プロジェクト「低消費電力型超電導ネットワークデ バイスの開発」基本計画 http://www.nedo.go.jp/activities/ portal/gaiyou/p02033/h18kihon.pdf

3) M. Drojevets, et al.: "COOL-0: Design of an RSFQ subsystem for petaflops computing", IEEE Trans. Appl. Supercond. 9 (1999) 3606-3614

4) P. Bunyk, et al.: "FLUX-1 RSFQ microprocessor", IEEE Trans. Appl. Supercond. 13 (2003) 433-436

5) O.A. Mukhanov, et al.: "Superconductor digital-RF receiver systems”, IEICE Trans. Electron. E91-C (2008) 306-317

6) H. Rogalla: "Fluxonics and superconducting electronics in Europe”, IEICE Trans. Electron. E91-C (2008) 272-279

7) K.K. Likharev and V.K. Semenov: "RSFQ logic/memory family; A new Josephson-junction technology for sub-terahertz-clock frequency digital systems", IEEE Trans. Appl. Supercond. 1 (1991) 3-28
8)「低消費電力型超電導ネットワークデバイスの開発」プロ ジェクト成果の詳細 http://www.nedo.go.jp/iinkai/kenkyuu/ bunkakai/19h/jigo/4/1/index.html

9) M. Hidaka, et al.: "Improvements in fabrication process for $\mathrm{Nb}-$ based single flux quantum circuits in Japan”, IEICE Trans. Electron. E91-C (2008) 318-324

10) H. Akaike, et al.: "Demonstration of a $120 \mathrm{GHz}$ single-flux quantum shift register circuit based on a $10 \mathrm{kAcm}^{-2} \mathrm{Nb}$ process", Supercond. Sci. Technol. 19 (2006) 320-324

11) Y. Kameda, et al.: "A new design methodology for single-fluxquantum (SFQ) circuits using passive transmission-line wirings", IEEE Trans. Appl. Supercond. 17 (2007) 508-511

12) Y. Kameda, et al.: " $40 \mathrm{GHz}$ operation of a single-flux-quantum (SFQ) switch scheduler”, HOT CHIPS (2005) 17

13) Y. Hashimoto, et al.: "Implementation of a $4 \times 4$ switch with passive interconnects", IEEE Trans. Appl. Supercond. 15 (2005) 356-359

14) Y. Hashimoto, et al.: "Demonstration of chip-to-chip transmission of single-flux-quantum pulses at throughputs beyond $100 \mathrm{Gbps",}$ Appl. Phys. Lett. 87 (2005) 022502

15) Y. Kameda, et al.: "Design and demonstration of a $4 \times 4$ SFQ network switch prototype and 10-Gbps bit-error-measurement", IEICE Trans. Electron. E91-C (2008) 333-341

16) Y. Hashimoto, et al.: "Development of cryopackaging and $\mathrm{I} / \mathrm{O}$ technologies for high speed superconductive digital systems", IEICE Trans. Electron. E91-C (2008) 325-332

17) N. Fujimaki, et al.: "Bit-serial single flux quantum microprocessor CORE", IEICE Trans. Electron. E91-C (2008) 342-349

18) K. Tanbe, et al.: "Advances in high-Tc single flux quantum device technologies”, IEICE Trans. Electron. E91-C (2008) 280-292

19) H. Wakana, et al.: "Improvement of critical current density uniformity for interface-modified junctions in single flux quantum circuits", Jpn. J. Appl. Phys. 45 (2006) L105-L107

20) H. Suzuki, et al.: "Stand-alone portable HTS sampler system", Ext. Abs. ISEC (2007) O-R01

21) F. Furuta, et a1.: "Superconductor/semiconductor hybrid analogto-digital converter", IEICE Trans. Electron. E91-C (2008) 356363

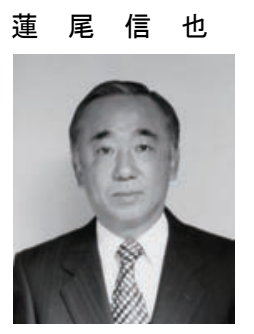

昭和 19 年生。昭和 42 年東京工業大学理工 学部電子工学科卒業。昭和 44 年同大学院理 工学研究科修士課程修了。昭和 47 年同博士 課程修了。昭和 47 年 4 月 (株) 富士通研究所 勤務。超電導デバイスの研究開発に従事。平 成 10 年、中国北京に富士通研究開発中心有 限公司を設立し、情報・通信・半導体の研究 開発を推進。平成 14 年から財国際超電導産 業技術研究センター超電導工学研究所勤務。応用物理学会, 電子 情報通信学会、IEEE 会員。工学博士。 